\title{
Adverse events and antibody response to accelerated immunisation in term and preterm infants
}

\author{
M E Ramsay, E Miller, L A E Ashworth, T J Coleman, M Rush, P A Waight
}

\begin{abstract}
A study was performed to compare adverse events and antibody response in term and preterm children vaccinated with diphtheria, tetanus, and pertussis vaccine at 2,3 , and 4 months of age. $A$ total of 124 children were recruited and grouped according to gestational age: 37 weeks or more $(n=52), 34$ to 36 weeks $(n=40)$, and less than 34 weeks $(n=32)$. Study nurses followed up children 24 hours after each vaccination to record temperature, redness, and swelling at the injection site and any systemic symptoms. Proportions of children experiencing adverse events did not differ between groups. Blood samples were obtained six weeks after the vaccination course at which time all children had protective levels of diphtheria and tetanus antitoxins. Geometric mean antibody titres (95\% confidence interval) to pertussis toxin were 2754 (2042 to 3715), 5495 (4074 to 7413$)$, and 3690 (2951 to 4677$)$, to filamentous haemagglutinin were 541 (282 to 1023), 951 (537 to 1698), and 614 (426 to 1023), and to agglutinogens 2 and 3 were 12106 (6918 to 21380 ), 21330 (13 183 to $34674)$, and 22387 (15 136 to 33113 ) in children born at a gestational age of less than 34 weeks, 34 to 36 weeks, and 37 weeks or more respectively. These findings support the current recommendations that preterm children are vaccinated at chronological age according to the national schedule.

(Arch Dis Child 1995; 72: 230-232)
\end{abstract}

Keywords: vaccination, diphtheria, tetanus, and pertussis vaccine, preterm.

In 1989 , antibody levels after primary immunisation at 3, 5, and 10 months of age were shown to be equivalent in term and preterm infants in the UK. ${ }^{1}$ It is therefore recommended that preterm children in the UK should be vaccinated at chronological age according to the national schedule. ${ }^{2}$ Since May 1990, however, children in the UK have been scheduled to receive accelerated immunisation with three doses of diphtheria, tetanus, and pertussis (DTP) vaccine at 2,3 , and 4 months of age. ${ }^{2}$ Studies to compare antibody responses and adverse reactions to vaccination at accelerated and prolonged schedules in term children have been reassuring, ${ }^{4-8}$ but no studies in preterm children have been performed with the UK accelerated schedule. This study was performed to compare the incidence of adverse events and the antibody response in term and preterm children after vaccination with UK whole cell DTP vaccine at 2,3 , and 4 months of age.

\section{Methods}

Infants born between April and December 1991 at or below 36 weeks of gestational age were recruited from the special care baby unit at a district general hospital in north Hertfordshire. Gestational age was determined by ultrasound scan or, where not available, by maternal dates. A term comparison group was recruited from antenatal clinics in north Hertfordshire among mothers booked to deliver between August 1991 and January 1992 at the same hospital. Parents were referred by hospital and clinic staff to study nurses who explained the purpose of the study and obtained written consent.

All children were scheduled to receive three doses of adsorbed DTP vaccine at approximately 2,3 , and 4 months of age. Vaccinations were given in the routine manner by hospital or community staff. The parents or ward staff were then asked to record axillary temperatures twice daily and the presence of redness or swelling at the injection site for three days after each dose of vaccine. In addition, the study nurse visited the ward or the home approximately 24 hours after each vaccination, took a rectal temperature, and recorded the maximum diameter of redness and swelling at the injection site. The parent was also asked to record the presence or absence of five systemic symptoms (vomiting, irritability, crying more than usual, taking less feed, and being more sleepy) in the 24 hour period after each vaccination.

Heel prick or venous blood samples were collected on the special care baby unit or at home before starting vaccination and 6-8 weeks after vaccination. Where possible, blood was collected at the same time as routine samples. Blood was tested for IgG antibodies to pertussis toxin, filamentous haemagglutinin (FHA), and agglutinogens 2 and 3 (AGGs2,3) by enzyme linked immunosorbent assay (ELISA) at the Public Health Laboratory Service Centre for Applied Microbiology and Research. ${ }^{9}$ Remaining sera was tested for tetanus and then diphtheria antitoxin levels at Hereford Public Health Laboratory by ELISA $^{10}$ and concentrations quantified in international units by comparison with 
Table 1 Adverse events in the first 24 hours after third dose vaccination

\begin{tabular}{|c|c|c|c|c|c|c|}
\hline \multirow{3}{*}{$\begin{array}{l}\text { Gestation } \\
\text { (weeks) }\end{array}$} & \multicolumn{2}{|c|}{ Reaction at the injection site } & \multirow{2}{*}{\multicolumn{2}{|c|}{ Rectal temperature }} & \multirow{2}{*}{\multicolumn{2}{|c|}{ Systemic symptoms }} \\
\hline & Redness & Swelling & & & & \\
\hline & $\geqslant 2.5 \mathrm{~cm}$ & $\geqslant 2.5 \mathrm{~cm}$ & $\geqslant 99^{\circ} \mathrm{F}$ & $\geqslant 100^{\circ} \mathrm{F}$ & $\geqslant 1$ & $\geqslant 2$ \\
\hline $\begin{array}{l}<34 \\
34-36 \\
\geqslant 37\end{array}$ & $\begin{array}{l}2 / 27 \\
2 / 34 \\
\mathbf{4} / 42\end{array}$ & $\begin{array}{l}1 / 27 \\
2 / 34 \\
4 / 42\end{array}$ & $\begin{array}{l}21 / 26 \\
24 / 32 \\
29 / 41\end{array}$ & $\begin{array}{r}5 / 26 \\
6 / 32 \\
10 / 41\end{array}$ & $\begin{array}{l}17 / 27 \\
19 / 36 \\
21 / 46\end{array}$ & $\begin{array}{r}9 / 27 \\
12 / 36 \\
14 / 46\end{array}$ \\
\hline
\end{tabular}

*One of the following: vomiting, irritability, crying more than usual, taking less feed, being more

NB: denominators are those where the measurement was taken at the correct time.
NB:

reference sera supplied by the National Institute for Biological Standards and Control.

For the purposes of statistical testing, results for children born at a gestational age of less than 37 weeks were pooled and compared with those born at 37 weeks or more. Proportions of children experiencing adverse events in term and preterm groups were compared using $\chi^{2}$ tests. Geometric mean antibody levels were compared between term and preterm children using Student's $t$ test applied to the log transformed data. In addition, linear regression of $\log$ antibody levels after vaccination on gestational age in weeks was performed for the whole group.

\section{Results}

A total of 124 children were recruited and categorised into three groups according to gestational age: 37 weeks or over $(n=52), 34$ to 36 weeks $(n=40)$, and less than 34 weeks $(n=32)$. One child in each group was lost to follow up after the prevaccination blood sample was taken. Two other children were excluded because they changed to diphtheriatetanus only vaccine after the first dose: one born at 35 weeks' gestation who had an axillary temperature of $105^{\circ} \mathrm{F}$ on the first evening and one born at 40 weeks' gestation where further pertussis was deferred for investigation of a possible neurological disorder. A further 10 children (four born at less than 34 weeks, two born between 34 and 36 weeks, and four born at 37 or more weeks' gestation) were excluded from analysis because they completed third dose vaccination after the age of 24 weeks.

Among children included in the final analysis, 10 (all born before 34 weeks' gestation) were of very low birth weight (below $1500 \mathrm{~g}$ ), and 35 were of low birth weight (1500-2499 g): 16/27 (59\%) born before 34 weeks, $17 / 36(47 \%)$ born at 34 to 36 weeks, and $2 / 46(4 \cdot 4 \%)$ born at 37 or more weeks' gestation.

Table 2 Antibody levels to diphtheria and tetanus

\begin{tabular}{|c|c|c|c|c|c|c|}
\hline \multirow[b]{2}{*}{$\begin{array}{l}\text { Gestation } \\
\text { (weeks) }\end{array}$} & \multicolumn{3}{|c|}{ Tetanus antitoxin $(I U / m l)$} & \multicolumn{3}{|c|}{ Diphtheria antitoxin (IU/ml) } \\
\hline & $\begin{array}{l}\text { No } \\
\text { tested }\end{array}$ & $\begin{array}{l}\mathrm{No}(\%) \\
>0.01\end{array}$ & $\begin{array}{l}\text { Geometric mean levels } \\
(95 \% \mathrm{CI})\end{array}$ & $\begin{array}{l}\text { No } \\
\text { tested }\end{array}$ & $\begin{array}{l}\mathrm{No}(\%) \\
>0.01\end{array}$ & $\begin{array}{l}\text { Geometric mean levels } \\
(95 \% \mathrm{CI})\end{array}$ \\
\hline $\begin{array}{c}\text { Before vacc } \\
<34 \\
34-36 \\
\geqslant 37\end{array}$ & $\begin{array}{c}\text { nation } \\
24^{\star} \\
29 \\
40\end{array}$ & $\begin{array}{l}23(96) \\
29(100) \\
39(98)\end{array}$ & $\begin{array}{l}0.18(0.11 \text { to } 0.30) \\
0.20(0.12 \text { to } 0.34) \\
0.38(0.25 \text { to } 0.59)\end{array}$ & $\begin{array}{l}14 \dagger \\
24 \\
31\end{array}$ & $\begin{array}{l}10(71) \\
21(88) \\
23(74)\end{array}$ & $\begin{array}{l}0.047(0.018 \text { to } 0.13) \\
0.035(0.024 \text { to } 0.052) \\
0.087(0.046 \text { to } 0.17)\end{array}$ \\
\hline $\begin{array}{c}\text { After vaccir } \\
<34 \\
\quad 34-36 \\
\geqslant 37\end{array}$ & $\begin{array}{c}\text { ation } \\
27 \\
32 \\
41\end{array}$ & $\begin{array}{l}27(100) \\
32(100) \\
41(100)\end{array}$ & $\begin{array}{l}0.42(0.28 \text { to } 0.62) \\
0.73(0.47 \text { to } 1.12) \\
0.66(0.50 \text { to } 0.87)\end{array}$ & $\begin{array}{l}22 \\
30 \\
39\end{array}$ & $\begin{array}{l}22(100) \\
30(100) \\
39(100)\end{array}$ & $\begin{array}{l}1.02(0.62 \text { to } 1.70) \\
1.31(0.89 \text { to } 1.95) \\
1.37(0.98 \text { to } 1.90)\end{array}$ \\
\hline
\end{tabular}

*Includes five children who received blood products before starting vaccination. IIncludes two children who received blood products before starting vaccination. $\mathrm{CI}=$ confidence interval.
According to parents' records, the proportion of children who experienced mild fever or local reactions after each dose of vaccination was similar in term and preterm groups. At 24 hour follow up there was no difference between these groups in the number of children experiencing adverse events ( $p>0.32)$ (table 1).

Unfortunately, a batch of eight prevaccination and seven postvaccination samples were lost in transit to the laboratory and the results for these children are missing in tables 2 and 3. In addition, eight prevaccination and two postvaccination samples were of insufficient volume for tetanus antitoxin determination and 32 prevaccination and 11 postvaccination samples were insufficient for diphtheria antitoxin determination.

Before vaccination, geometric mean levels of antibody were lower in the preterm group than in the term group for tetanus $(p=0.01)$, diphtheria $(p=0.02)$, and pertussis toxin $(p=0.02)$ (tables 2 and 3$)$. After vaccination, all children had diphtheria and tetanus antitoxin levels above the minimum protective level $\left(0.01 \mathrm{IU} / \mathrm{ml}\right.$ ) (table 2). ${ }^{11} 12$ Two children, born at 27 weeks and at 36 weeks' gestation, had diphtheria antitoxin levels below the higher level recommended for individual protection $(0.10 \mathrm{IU} / \mathrm{ml}) .{ }^{12}$ The proportion of children with pertussis antibody titres below detectable levels did not differ between groups (table 3 ).

Geometric mean levels of diphtheria and tetanus antitoxin and geometric mean titres to each pertussis antigen were similar in term and preterm groups after vaccination ( $p>0.27)$. Regression of $\log$ antibody levels on gestational age revealed no significant trend for diphtheria antitoxin, for FHA antibody or for pertussis toxin antibody $(p>0 \cdot 16)$. A small trend towards higher antibody levels with higher gestational age was demonstrated for tetanus $(p=0.04)$ and for AGGs2,3 $(p=0.02)$.

\section{Discussion}

The study has demonstrated that preterm children suffer no more adverse events than term children when vaccinated with DTP vaccine at chronological age according to the UK national schedule. In addition, the vast majority of preterm children develop protective antitoxin levels to diphtheria and tetanus. Although trends towards higher levels of tetanus antitoxin and AGGs2,3 antibody were observed with increasing gestational age, the differences in postvaccination antibody levels between term and preterm children were small and less than the differences between groups in prevaccination levels. The lower antibody levels observed before vaccination suggests that preterm children are at greater risk from vaccine preventable disease and therefore require vaccination at an equivalent or earlier age than term infants.

The findings of this study are reassuring and in accordance with previous work from the USA which demonstrated similar antibody levels in term and preterm infants after three doses of vaccine at 2, 4, and 6 months of 
Table 3 Antibody titres to pertussis antigens

\begin{tabular}{|c|c|c|c|c|c|c|c|}
\hline \multirow[b]{2}{*}{$\begin{array}{l}\text { Gestation } \\
\text { (weeks) }\end{array}$} & \multirow[b]{2}{*}{$\begin{array}{l}\text { No } \\
\text { tested }\end{array}$} & \multicolumn{2}{|c|}{$F H A($ titres $/ m l)$} & \multicolumn{2}{|c|}{ Pertussis toxin (titres/ml) } & \multicolumn{2}{|c|}{ AGGs2,3 (titres $/ \mathrm{ml}$ ) } \\
\hline & & $\begin{array}{l}\text { No(\%) } \\
\text { positive }\end{array}$ & $\begin{array}{l}\text { Geometric mean titre } \\
(95 \% \text { CI })\end{array}$ & $\begin{array}{l}\text { No(\%) } \\
\text { positive }\end{array}$ & $\begin{array}{l}\text { Geometric mean titre } \\
(95 \% \text { CI })\end{array}$ & $\begin{array}{l}\text { No(\%) } \\
\text { positive }\end{array}$ & $\begin{array}{l}\text { Geometric mean titre } \\
(95 \% \text { CI })\end{array}$ \\
\hline \multicolumn{8}{|c|}{ Before vaccination } \\
\hline $\begin{array}{l}<34 \\
34-36 \\
\geqslant 37\end{array}$ & $\begin{array}{l}26^{\star} \\
31 \dagger \\
44\end{array}$ & $\begin{array}{l}24(92) \\
31(100) \\
43(98)\end{array}$ & $\begin{array}{l}475(339 \text { to } 676) \\
731(490 \text { to } 1071) \\
805(537 \text { to } 1202)\end{array}$ & $\begin{array}{l}16(62) \\
27(87) \\
34(77)\end{array}$ & $\begin{array}{l}202(155 \text { to } 263) \\
243(162 \text { to } 372) \\
370(257 \text { to } 537)\end{array}$ & $\begin{array}{l}12(50) \\
19(62) \\
29(66)\end{array}$ & $\begin{array}{l}261 \text { (158 to } 427) \\
897 \text { (501 to } 1585) \\
543 \text { (355 to } 832)\end{array}$ \\
\hline \multicolumn{8}{|c|}{ After vaccination } \\
\hline $\begin{array}{l}<34 \\
\quad 34-36 \\
\geqslant 37\end{array}$ & $\begin{array}{l}27 \\
34 \\
41\end{array}$ & $\begin{array}{l}27(100) \\
33(97) \\
41(100)\end{array}$ & $\begin{array}{l}2754(2042 \text { to } 3715) \\
5495(4074 \text { to } 7413) \\
3690(2951 \text { to } 4677)\end{array}$ & $\begin{array}{l}24(89) \\
33(97) \\
38(93)\end{array}$ & $\begin{array}{l}541(282 \text { to } 1023) \\
951(537 \text { to } 1698) \\
614(426 \text { to } 1023)\end{array}$ & $\begin{array}{l}27(100) \\
34(100) \\
41(100)\end{array}$ & $\begin{array}{l}12106(6918 \text { to } 21380) \\
21330(13183 \text { to } 34674) \\
22387(15136 \text { to } 33113)\end{array}$ \\
\hline
\end{tabular}

$\star$ Includes five children who received blood products before starting vaccination.

tIncludes one child who received blood products before starting vaccination.

$\mathrm{CI}=$ confidence interval.

age. ${ }^{13}$ The American study, however, did demonstrate reduced antibody levels among preterm children after the first dose of vaccine. Because this reduction was attributed to immunological immaturity, there was concern that an accelerated schedule, such as that used in the UK or recommended by the World Health Organisation, ${ }^{14}$ could result in preterm children having a substantially reduced overall response to vaccination. In this study, because of the short interval between doses of vaccine, we were unable to measure dose specific antibody responses. The antibody levels observed after completion, however, suggest that the immunological immaturity of preterm infants is not a cause for major concern with the UK schedule. As vaccination against Haemophilus influenzae type $\mathrm{b}$ was not introduced in the UK until 1992, however, antibody levels to $H$ influenzae type $\mathrm{b}$ were not measured in this study. A study in preterm infants with chronic lung disease in the USA suggested that antibody levels after two doses of $H$ influenzae type $b$ vaccine were lower in preterm than term infants, ${ }^{15}$ but preterm infants have been shown to mount an adequate immune response to accelerated immunisation with three doses of $H$ influenzae type $\mathrm{b}$ vaccine in the UK. ${ }^{16}$

Our study included only a small number of very low birthweight children (less than $1500 \mathrm{~g}$ ) and would not have sufficient power to detect a reduced antibody response in this group. Very low birthweight children, however, constituted only $1.0 \%$ of live births in England and Wales in 1992, whereas the low birthweight group (1500-2499 g), accounted for about $5 \cdot 8 \%$ (unpublished data, Office of Population Censuses and Surveys). This larger group would be expected to have more influence on the maintenance of herd immunity in the UK. The demonstration of a good antibody response among the preterm children recruited in this study is therefore more relevant to the overall control of vaccine preventable disease. Our findings provide support for the current recommendations that preterm children in the UK should be vaccinated at chronological age. $^{2}$

We thank Paddy Farrington for statistical advice, Carol Thornton and Sue Kench for technical assistance, and the study nurses Lynn Joslin, Norah Ashwood, Micaela Hobbs, Mary Heath, and Maureen Wheal. We are also grateful to the midwives, nurses, and doctors in the delivery suite and the special care baby unit at the Lister Hospital. This study was funded by the Department of Health.

1 Pullan CR, Hull D. Routine immunisation of preterm infants. Arch Dis Child 1989; 64: 1438-41.

2 Department of Health. Immunisation against infectious disease, 1994. London: HMSO, 1994

3 Department of Health. Immunisation against infectious disease. London: HMSO, 1990.

4 Halsey N, Galazka A. The efficacy of DPT and oral poliomyelitis immunisation schedules initiated from birth to 12 weeks of age. Bull World Health Organ 1985; 63: 1151-69.

5 Ramsay MEB, Begg NT, Ashworth LAE, Corbel MA, Redhead K. Persistence of antibody following accelerated immunisation with diphtheria/tetanus/pertussis vaccine. BMF 1991; 302: 1489-91.

6 Ramsay MEB, Rao M, Begg NT. Symptoms following accelerated immunisation. BMF 1992; 304: 1534-6.

7 Booy R, Aitken SJM, Taylor S, et al. Immunogenicity of combined diphtheria, tetanus, and pertussis vaccine given combined diphtheria, tetanus, and pertussis vaccine given at 2,3 , and 4 months of age vers
age. Lancet 1992; 339: 507-10.

8 Ramsay MEB, Rao M, Begg NT, Redhead K, Attwell A-M Antibody response to accelerated immunisation with diphtheria, tetanus, pertussis vaccine. Lancet 1993; 342: 203-5.

9 Miller E, Ashworth LAE, Robinson A, Waight PA, Irons LI. Phase II trial of whole cell pertussis vaccine vs an acellular vaccine containing agglutinogens. Lancet 1991; 337: $70-3$.

10 Melville-Smith $M$. Diphtheria and tetanus antitoxins. In: Wreghitt TG, Morgan-Capner $\mathrm{P}$, eds. ELISA in the clinical microbiology laboratory. London: Public Health clinical microbiology laboratory. Lo.

11 Smith JWG. Diphtheria and tetanus toxoid. Br Med Bull 1969; 25: 177-82.

12 World Health Organisation. The control of diphtheria in Europe. Report on a WHO meeting. Copenhagen: WHO,

13 Bernbaum JC, Daft A, Anolik R, et al. Response of preterm infants to diphtheria-tetanus-pertussis immunizations. $\mathcal{F}$ Pediatr 1985; 107: 184-8.

14 Hall AJ, Greenwood BM, Whittle H. Practice in developing countries. Lancet 1990; 335: 774-7.

15 Washburn LK, O'Shea M, Gillis DC, Block SM, Abramson JS. Response to Haemophilus influenzae type b conjugate vaccine in chronically ill premature infants. $\Im$ Pediatr 1993; 123: 791-4.

16 Booy R, Moxon ER, Mayon-White RT, Slack MPE, MacFarlane JA. Vaccination against $H$ influenzae type $b$. $B M \mathcal{F}$ 1993; 306: 63 . 